\title{
GRANULOMA PIOGÊNICO - RELATO DE CASO CLÍNICO
}

Nayana BRUNETTA, Maria Teresa DARIVA, Paulo Sérgio BATISTA, Antônio Adilson Soares de LIMA, Luciana Reis AZEVEDO

O granuloma piogênico consiste de uma reação excessiva do tecido conjuntivo frente a agentes irritantes, como cálculo dentário, corpos estranhos e trauma. O objetivo deste trabalho é relatar um caso clínico de granuloma piogênico e enfatizar a importância da remoção do agente irritante no sucesso do tratamento. Paciente do sexo masculino, 44 anos, foi encaminhado à clínica de Estomatologia da PUCPR para tratamento de lesão nodular em rebordo alveolar. Relatou que a lesão apareceu logo depois que a coroa protética do dente 46 foi cimentada, há 1 ano. Havia sangramento no momento da higienização. Ao exame físico intrabucal, foi observada presença de nódulo, de coloração avermelhada, sangrante, que se estendia de vestibular para lingual entre os dentes 45 e 46, além de cálculo dentário no local. A radiografia periapical da região mostrou excesso de material restaurador na face distal do dente 45 e falta de adaptação da coroa protética na mesial do dente 46. As hipóteses de diagnóstico foram granuloma piogênico e lesão periférica de células gigantes. Foi realizada biópsia excisional e o material foi submetido à análise histopatológica. $\mathrm{O}$ diagnóstico final foi granuloma piogênico. O paciente foi encaminhado para tratamento periodontal e restaurador. Com 2 meses pós-operatório, não há sinal de recidiva. 